HOME IN AMERICA 



\title{
Home in America
}

\section{On Loss and Retrieval}

\author{
Thomas Dumm
}

The Belknap Press of

Harvard University Press

Cambridge, Massachusetts

London, England 2019 
Copyright (C) 2019 by the President and Fellows of Harvard College

All rights reserved

Printed in the United States of America

First printing

Cover design: Tim Jones

Cover image: Photograph @ Dave Reede/Getty Images

$$
\begin{gathered}
9780674243798 \text { (EPUB) } \\
9780674243804 \text { (MOBI) } \\
9780674243781 \text { (PDF) }
\end{gathered}
$$

The Library of Congress has cataloged the printed edition as follows:

Names: Dumm, Thomas L., author.

Title: Home in America : on loss and retrieval/Thomas Dumm.

Description: Cambridge, Massachusetts : The Belknap Press of Harvard University Press, 2019. Identifiers: LCCN 2019017829 | ISBN 9780674057715 (hardcover)

Subjects: LCSH: Home-United States-History. | Home in popular culture-United States-History. | Home in literature. | United States-Race relations-History.

Classification: LCC HQ535 .D76 2019 | DDC 306.850973-dc23

LC record available at https://lccn.loc.gov/2019017829 
For fudy 
